\title{
Multiple G-Protein-dependent Pathways Mediate the Antisecretory Effects of Somatostatin and Clonidine in the HT29-19A Colonic Cell Line
}

\author{
G. Warhurst, L. A. Turnberg, N. B. Higgs, A. Tonge, J. Grundy, and K. E. Fogg \\ The Epithelial Membrane Research Centre and Department of Medicine, University of Manchester, \\ Hope Hospital, Salford M6 8HD, United Kingdom
}

\begin{abstract}
Using the functionally differentiated colonic cell line, HT29. 19A, we have examined sites at which inhibitory G-proteins mediate the antisecretory actions of somatostatin (SST) and the $\alpha_{2}$-adrenergic agonist, clonidine (CLON) at the epithelial level. Both agents caused a dose-dependent inhibition $\left(\mathrm{EC}_{\mathbf{5 0}}\right.$ : SST $35 \mathrm{nM}$; CLON $225 \mathrm{nM}$ ) of $\mathrm{Cl}^{-}$secretion (assessed by changes in short circuit current) activated by cAMP-mediated agonists, $\mathrm{PGE}_{2}$ and cholera toxin. Inhibition was accompanied by a reduction in intracellular CAMP accumulation and could be blocked by pretreatment with pertussis toxin at a concentration ( $200 \mathrm{ng} / \mathrm{ml}$ ) which activated ADP-ribosylation of a 41-kD inhibitory G protein in HT29-19A membranes. Secretion stimulated by the permeant cAMP analogue, dibutyryl cAMP, was also inhibited by SST and CLON (30-50\%; $P<0.005)$, indicating additional inhibitory sites located distal to CAMP production. Both agents were effective inhibitors of secretion mediated through the $\mathrm{Ca}^{2+}$ signaling pathway. SST (1 $\left.\mu \mathrm{M}\right)$ and CLON $(10 \mu \mathrm{M})$ reduced the Isc response to the muscarinic agonist, carbachol, by $60-70 \%$; inhibition was reversed in pertussis toxin-treated cells. These effects did not, however, involve inhibition of the carbachol-induced increase in cellular inositol 1,4,5-trisphosphate levels or the rise in cytosolic calcium, $[\mathrm{Ca}]_{\mathbf{i}}$. Inhibition by SST of secretion induced by phorbol 12,13 dibutyrate but not by the calcium agonist, thapsigargin, suggests that SST may act at a distal inhibitory site in the $\mathrm{Ca}^{2+}$-dependent secretory process activated by protein kinase $\mathrm{C}$. We conclude that SST and $\alpha_{2}$-adrenergic agonists can act directly on intestinal epithelial cells to exert a comprehensive inhibition of $\mathrm{Cl}^{-}$secretion mediated through both $\mathrm{CAMP}$ and $\mathrm{Ca}^{2+} / \mathrm{pro}-$ tein kinase $C$ signaling pathways. Inhibition is mediated via pertussis toxin-sensitive $\mathbf{G}$-proteins at sites located both proximal and distal to the production of second messengers. ( $\mathrm{J}$. Clin. Invest. 1993. 92:603-611.) Key words: $\alpha_{2}$-adrenergic $\bullet$ cyclic adenosine monophosphate • inhibitory G-protein • intestinal epithelial cell • ion secretion • somatostatin
\end{abstract}

\section{Introduction}

Somatostatin (SST) ${ }^{1}$ and alpha-2-adrenergic agonists $\left(\alpha_{2}-\right.$ ADR) are potent inhibitors of CAMP- and $\mathrm{Ca}^{2+}$-mediated se-

Address reprint requests to Dr. G. Warhurst, Department of Medicine, Hope Hospital Eccles Old Road, Salford M6 8HD, United Kingdom. Received for publication 29 August 1991 and in revised form 1 March 1993.

1. Abbreviations used in this paper: $\alpha_{2}$-ADR, $\alpha_{2}$-adrenergic; CLON, clonidine; CT, cholera toxin; db-cAMP, dibutyl cAMP; $\mathrm{G}_{i}$, inhibitory

J. Clin. Invest.

(C) The American Society for Clinical Investigation, Inc.

0021-9738/93/08/0603/09 \$2.00

Volume 92, August 1993, 603-611 cretion in the mammalian intestine (1-4). Both show promise as therapeutic agents in the treatment of secretory disorders (5). The cellular sites of action of these agonists and/or the nature of their molecular interaction with the secretory process, however, remain poorly defined. Evidence that tetrodotoxin and other neuronal blockers can inhibit the actions of SST and $\alpha_{2}$-ADR in some species suggests that the enteric nervous system may be an important site of action $(2,6)$. However, the identification of specific receptor sites for both types of agonist on enterocyte membranes $(7,8)$ implies a direct action mediated at the epithelial level.

In several systems SST and $\alpha_{2}$-ADR have been shown to mediate their cellular effects through the receptor activation of inhibitory $G$-proteins $\left(G_{i}\right)$ coupled to the inhibition of adenylate cyclase $(9,10)$ and other membrane events including modulation of $\mathrm{K}^{+}$and $\mathrm{Ca}^{2+}$ channels $(11,12)$. Recent evidence suggests that $G_{i}$ proteins are expressed in enterocytes and may mediate the receptor-activated inhibition of cAMP production (13) but we have little information on their role in attenuating secretory responses.

Recent studies using human colonic adenocarcinoma cell lines suggest that they may be useful models with which to address these questions. HT29 cells have been shown to express $\alpha_{2}$-ADR receptors coupled to the inhibition of adenylate cyclase $(14,15)$ and other mechanisms (16) though no attempt was made to investigate their linkage to ion transport processes. In the T84 cell line SST at high concentrations was reported to attenuate ion secretory responses (17) though the molecular mechanism of inhibition was not investigated.

In this study we have used the HT29-19A cell line, a differentiated subclone of HT29 that actively secretes $\mathrm{Cl}^{-}$in response to neurohumoral agonists (18) to examine in greater detail the effects of SST and CLON in a pure epithelium. Our data suggest that both agents can inhibit CAMP- and $\mathrm{Ca}^{2+} /$ protein kinase $\mathrm{C}$ (PKC)-activated secretion, and that these effects are mediated by pertussis toxin (PT)-sensitive G-proteins directed at multiple sites along the secretory pathway located both proximal and distal to the generation of second messengers.

\section{Methods}

Cell culture. The HT29-19A colonic adenocarcinoma cell line was kindly supplied by Dr C. Laboisse, INSERM, Paris, and used between passages 38 and 52. Cells were grown in DME supplemented with 15 $\mathrm{mM}$ Hepes, $2 \mathrm{mM}$ glutamine, $50 \mathrm{IU} / \mathrm{ml}$ penicillin, $50 \mu \mathrm{g} / \mathrm{ml}$ streptomycin, and $10 \%$ fetal calf serum in a humidified atmosphere of $5 \%$ $\mathrm{CO}_{2} / 95 \%$ air at $37^{\circ} \mathrm{C}$.

guanine-nucleotide-binding protein; IBMX, 3-isobutyl-1-methylxanthine; $\mathrm{IP}_{3}$, inositol, 1,4,5-trisphosphate; Isc, short circuit current; PDB, $4 \alpha$-phorbol, 12,13-dibutyrate; PKC, protein kinase C; PT, pertussis toxin; RT, transepithelial resistance; SST, somatostatin; THAP, thapsigargin. 
Monolayers of epithelial cells were formed on permeable filter supports. Cells were seeded at a density of $3 \times 10^{5} / \mathrm{cm}^{2}$ onto a collagencoated (rat tail; $2.5 \mathrm{mg} / \mathrm{ml}$ ) filter (Millipore Corp., Bedford, MA) to which had been glued a silicone washer leaving a growing area of 1.13 $\mathrm{cm}^{2}$. After seeding, filters were initially floated on medium in petri dishes and were submerged after $18 \mathrm{~h}$. Filters were used for transepithelial electrical studies 10-15 d after seeding. Under these conditions HT29-19A cells form a polarized epithelial monolayer (17). Cells grown on similar permeable supports were also used for measurements of intracellular cAMP (Millipore Corp.) or intracellular free calcium, $[\mathrm{Ca}]_{i}$ (Nunc, Copenhagen, DK). Cellular levels of inositol 1,4,5-trisphosphate $\left(\mathrm{IP}_{3}\right)$ were measured in cells grown to confluency in $22-\mathrm{mm}$ plastic dishes.

Measurements of transepithelial electrical responses. Changes in short circuit current (Isc) were used as an indicator of electrogenic ion transport (18). Electrical parameters (Isc and transepithelial resistance [RT]) were measured using the Ussing chamber technique previously described (19). Cells were bathed at $37^{\circ} \mathrm{C}$ with a bicarbonate-buffered Ringer's solution that was gassed continuously with $5 \% \mathrm{CO}_{2} / 95 \% \mathrm{O}_{2}$. Under these conditions HT29-19A cells exhibited a basal Isc of 3.2 \pm 0.2 $\mu \mathrm{A} / \mathrm{cm}^{2}$ and a mean RT of $234 \pm 12.6 \Omega / \mathrm{cm}^{2}(n=126)$. The Isc generated by these cells is assumed to be principally $\mathrm{Cl}^{-}$based on the observations that Isc stimulated by the CAMP agonist forskolin was $(a)$ abolished in $\mathrm{Cl}^{-}$-free media, $(b)$ inhibited over $80 \%$ by serosal application of $100 \mu \mathrm{M}$ bumetanide, and $(c)$ unaffected by apical application of 1 $\mathrm{mM}$ amiloride. In addition, a recent study has also shown that forskolin stimulates apical ${ }^{36} \mathrm{Cl}$ efflux in this cell line (20).

Determination of cellular cAMP. Cell monolayers grown on Millipore filters were rinsed several times with a Hepes-buffered Ringer's solution ( $15 \mathrm{mM}, \mathrm{pH} \mathrm{7.5)}$ and incubated in the same buffer with agonists for various times at $37^{\circ} \mathrm{C}$. Where indicated the phosphodiesterase inhibitor 3-isobutyl-1-methylxanthine (IBMX; $0.25 \mathrm{mM}$ ) was included to minimize cAMP breakdown. Incubations were stopped by rapid washing in ice-cold Ringer's solution $(<5 \mathrm{~s})$ and cellular cAMP extracted overnight at $-70^{\circ} \mathrm{C}$ into ethanol/.water (2:1). Extracts were dried under $\mathrm{N}_{2}$, reconstituted in Tris buffer ( $\mathrm{pH} 7.5$ ), and assayed for cAMP as previously described (19).

Determination of cellular $\mathrm{IP}_{3}$ production. Cells were grown to confluency in 22-mm plastic dishes. After aspiration of the growth medium, cells were incubated in Hepes-Ringer's solution for $2 \mathrm{~min}$ at $37^{\circ} \mathrm{C}$ before addition of agonists. Incubations $(0-5 \mathrm{~min})$ were terminated by the addition of ice-cold perchloric acid ( $4 \% \mathrm{vol} / \mathrm{vol}$ ) and kept on ice for $15 \mathrm{~min}$. Samples of the perchloric acid extract were neutralized by addition of $5 \mathrm{M} \mathrm{KOH}$ and centrifuged at $12,000 \mathrm{~g}$ for $5 \mathrm{~min}$ to remove $\mathrm{KClO}_{4}$ precipitate. Aliquots of the supernatant were assayed for $\mathrm{IP}_{3}$ using a binding protein isolated from bovine adrenal cortex as described by Palmer et al. (21). In some experiments, samples were assayed using a commercial $\mathrm{IP}_{3}$ assay kit (Amersham International, Amersham, UK) that uses the same binding protein. Both assay systems gave similar values for $\mathrm{IP}_{3}$ in HT29-19A extracts. Cross-reactivity of the binding protein with other inositol species including inositol 1,3,4-trisphosphate and inositol 1,3,4,5-tetrakisphosphate $\left(\mathrm{IP}_{4}\right)$ is $1 \%$ or less (21).

Measurement of intracellular calcium, $[\mathrm{Ca}]_{i},[\mathrm{Ca}]_{\mathrm{i}}$ was measured by dual excitation microfluorimetry using Fura-2 (22). Cells cultured for $5-7 \mathrm{~d}(80-90 \%$ confluent $)$ on $10-\mathrm{mm}$ polycarbonate tissue culture inserts (Nunc) were loaded in culture medium containing $10 \mu \mathrm{M}$ Fura2/ AM for $45-60 \mathrm{~min}$ at $37^{\circ} \mathrm{C}$. The monolayer was washed with Hepesbuffered Ringer's solution containing (in $\mathrm{mM}$ ) $141 \mathrm{NaCl}, 1.2 \mathrm{CaCl}_{2}$, 1.2 $\mathrm{MgCl}_{2}, 1.2 \mathrm{~K}_{2} \mathrm{HPO}_{4}, 1.8 \mathrm{KH}_{2} \mathrm{PO}_{4}, 5$ glucose, and 15 Hepes, $\mathrm{pH}$ 7.4. The tissue culture insert was mounted in a perfusion chamber on the stage of a Nikon Diaphot (Tokyo). Cells were perfused continuously at $2 \mathrm{ml} / \mathrm{min}$ on the basolateral surface with the same buffer at $22-24^{\circ} \mathrm{C}$. Buffer bathing the apical surface was not changed during the experiment. Cells were excited alternately by light of 350 and $380 \mathrm{~nm}$ by means of a motor-driven filter changer and the emitted fluorescence at $510 \mathrm{~nm}( \pm 10 \mathrm{~nm})$ from groups of four to six cells was monitored by photon counting (Newcastle Photometric Systems, Newcastle, UK). Fluorescence was corrected for background and autofluorescence be- fore calculation of the $350 / 380$ ratio, $R$. This routinely represented $<20 \%$ of the total signal. Where indicated, [Ca $]_{i}$ was also measured in cells grown on collagen-coated glass coverslips. In this case, background fluorescence was lower being routinely $<8 \%$ of the total signal.

$[\mathrm{Ca}]_{\mathrm{i}}$ was calculated with reference to a calibration curve relating [Ca $]_{i}$ (in nanomoles) to the 350/380 ratio. Values of $R$ were measured in vitro using commercially available $\mathrm{Ca}^{2+}$-EGTA buffer solutions yielding known free $\mathrm{Ca}^{2+}$ concentrations in the range 0-39.8 $\mu \mathrm{M}$ (Molecular Probes Inc., Eugene, OR) and containing $50 \mu \mathrm{M}$ Fura-2. $R$ values were measured in $20-\mu$ l droplets of each solution on a glass slide. Results are shown as representative tracings of at least four identical experiments.

ADP-ribosylation of HT29-19A membranes. PT-stimulated ADPribosylation of HT29-19A membranes was determined by a modification of the methods described by van den Berghe et al. (23) and Balda et al. (24). After incubation in the presence $(200 \mathrm{ng} / \mathrm{ml})$ or absence of PT for $18 \mathrm{~h}$ HT29-19A cells were washed, harvested, and homogenized in $25 \mathrm{mM}$ Tris $\mathrm{HCl}, \mathrm{pH} 7.5$, containing $1 \mathrm{mM}$ EDTA, $1 \mathrm{mM}$ DTT, and $10 \mu \mathrm{g} / \mathrm{ml}$ aprotinin. Membranes were prepared by centrifuging homogenates at $1,000 \mathrm{~g}$ for $15 \mathrm{~min}$ followed by recentrifugation of the resulting supernatant at $20,000 \mathrm{~g}$ for $20 \mathrm{~min}$. Membranes were resuspended in the same buffer and the protein content was determined. ADP-ribosylation was performed by incubating $150 \mu \mathrm{g}$ of membrane protein for $60 \mathrm{~min}$ at $32^{\circ} \mathrm{C}$ in a substrate mix (total volume $100 \mu \mathrm{l}$ ) containing 25 mM Tris- $\mathrm{HCl}, \mathrm{pH} 8.0,5 \mu \mathrm{M}\left[{ }^{32} \mathrm{P}\right] \mathrm{NAD}$ ( $5 \mu \mathrm{Ci} /$ assay), $2 \mathrm{mM}$ ATP, $0.1 \mathrm{mM} \mathrm{GTP}, 10 \mu \mathrm{g} / \mathrm{ml}$ creatine phosphokinase, $20 \mathrm{mM}$ creatine phosphate, $20 \mathrm{mM}$ thymidine, $0.5 \mathrm{mM} \mathrm{NADP}^{+}, 2.5 \mathrm{mM} \mathrm{MgSO}_{4}, 5 \mathrm{mM}$ EDTA, $1 \mathrm{mM}$ EGTA, $20 \mathrm{mM} \beta$-glycerophosphate, $5 \mathrm{mM}$ DTT, 5 $\mu \mathrm{g} / \mathrm{ml}$ leupeptin, $20 \mu \mathrm{g} / \mathrm{ml}$ trypsin inhibitor, $0.025 \%$ saponin, and $2 \mu \mathrm{g}$ of activated pertussis toxin (preactivated by incubation for $20 \mathrm{~min}$ at $37^{\circ} \mathrm{C}$ with $25 \mathrm{mM}$ DTT). Control incubations in the absence of PT were also included. Reactions were terminated by addition of $400 \mu \mathrm{l}$ of $20 \%$ trichloroacetic acid. Precipitated proteins were pelleted by centrifugation and the pellet washed once with $1 \mathrm{ml}$ of diethyl ether. After allowing excess ether to evaporate the pellets were solubilized by boiling for $5 \mathrm{~min}$ in $0.066 \mathrm{M}$ Tris- $\mathrm{HCl}, \mathrm{pH} 7.0$, containing $0.63 \mathrm{M}$ mercaptoethanol, $4 \%$ SDS, $10 \%$ glycerol, and $0.01 \%$ bromophenol blue. Proteins were separated by SDS-PAGE on $10 \%$ gels according to the method of Laemmli (25). After fixing and staining gels were dried and exposed for autoradiography with Kodak X-OMAT AR film.

Statistical analysis. Results are expressed as mean \pm SEM. All statistical comparisons were made using the unpaired Student's $t$ test. Differences were considered significant when $P<0.05$.

Materials. SST, CLON, PG $\mathrm{E}_{2}$, carbachol $(\mathrm{CCh})$, yohimbine, cholera toxin (CT), phorbol 12,13 dibutyrate, and dibutyryl cAMP (db-cAMP) were from Sigma Chemical, Poole, UK. Thapsigargin (THAP), Fura-2, and Fura-2/AM were purchased from Calbiochem Corp., La Jolla, CA. Radiolabeled cAMP and $\mathrm{IP}_{3}$ were from Amersham International, UK.

\section{Results}

SST and CLON inhibit cAMP-mediated secretion at sites proximal and distal to cAMP production. The cAMP agonist $\mathrm{PGE}_{2}$ caused a rapid and sustained increase in Isc across HT29-19A monolayers compatible with a stimulation of $\mathrm{Cl}^{-}$secretion (Fig. $1 A)$. Application of SST $(0.1 \mu \mathrm{M})$ to the basolateral bathing medium at the peak of the secretory response induced a rapid inhibition of Isc by $60-70 \%$ within 3 min of addition. Inhibition was sustained for at least $60 \mathrm{~min}$ in the continued presence of SST. The adrenergic agonist CLON $(10 \mu \mathrm{M})$ elicited a similar inhibitory response in $\mathrm{PGE}_{2}$-stimulated monolayers (Fig. $1 \mathrm{~B}$ ) reducing Isc by $85 \%$ within 2 min. Pretreatment with the $\alpha_{2}$-ADR receptor antagonist yohimbine ( 10 $\mu \mathrm{M}$ ) reduced CLON-induced inhibition by over $90 \%$ (results not shown). 
A

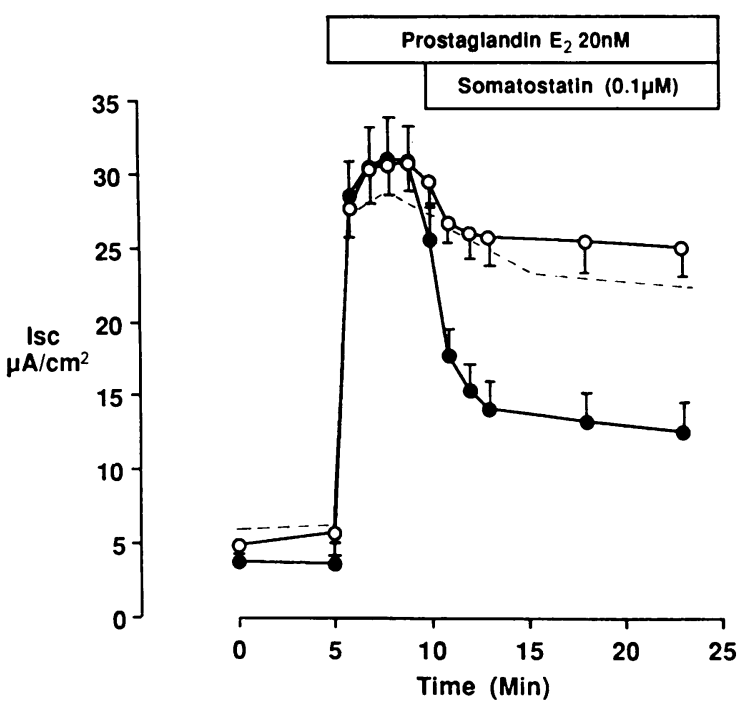

B

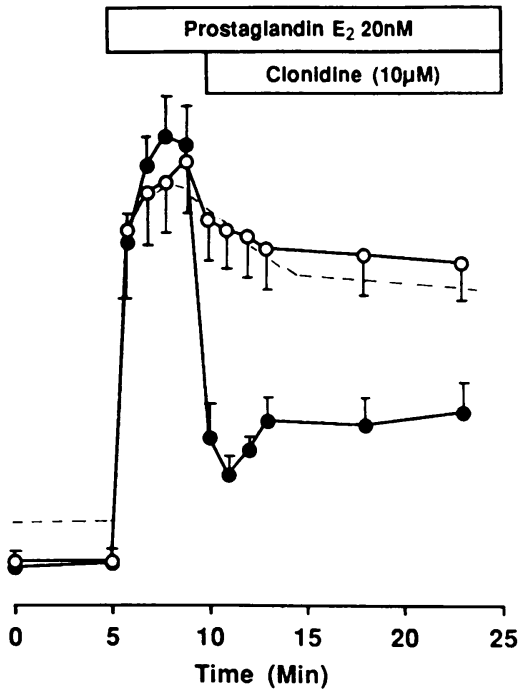

Figure 1. Effects of $(A)$ SST and $(B)$ CLON on the increase in Isc stimulated by 20 $\mathrm{nM} \mathrm{PGE}_{2}$. Studies were performed in $(\bullet)$ control cells and $(0)$ cells pretreated with $200 \mathrm{ng} / \mathrm{ml} \mathrm{PT}$ for $18 \mathrm{~h}$. Values are from five to seven filters in each group. Dashed line shows typical response to $20 \mathrm{nM} \mathrm{PGE}_{2}$ alone.
The inhibitory effects of SST on $\mathrm{PGE}_{2}$-stimulated secretion were dose dependent with a threshold at $1 \mathrm{nM}$ and a half-maximal response $\left(\mathrm{EC}_{50}\right)$ at $35 \mathrm{nM} \mathrm{SST} \mathrm{(Fig.} 2 \mathrm{~A}$ ). CLON-induced Isc inhibition was also dose-dependent although in this case the $\mathrm{EC}_{50}$ was significantly higher at $225 \mathrm{nM}$ (Fig. $2 \mathrm{~B}$ ). In both cases the $\mathrm{EC}_{50}$ values obtained in HT29-19A cells are similar to those reported for inhibition of fluid and electrolyte secretion in whole intestine $(6,26,27)$.

The reversal of $\mathrm{PGE}_{2}$-induced secretion by SST and CLON in HT29-19A monolayers was associated with a marked inhibition of cAMP production (Fig. 2). While for SST there was a close correlation between inhibition of Isc and cAMP $\left(\mathrm{EC}_{50}\right.$ 's 35 and $31 \mathrm{nM}$, respectively) there appeared to be some dissociation of these parameters using CLON. The half-maximal concentration of CLON required to inhibit Isc ( $225 \mathrm{nM})$ was significantly higher $(P<0.01)$ than that for cAMP $(70 \mathrm{nM})$ though the maximum level of inhibition was similar in both cases ( $82 \%$ vs. $79 \%$ ). These results suggest that attenuation of cAMP production is a significant component of the antisecretory effects of SST and CLON in HT29-19A cells.

The role of $\mathrm{G}_{\mathrm{i}}$-proteins in the reversal of $\mathrm{PGE}_{2}$-induced secretion by SST and CLON was assessed by pretreating monolayers with PT, known to inactivate $G_{i}$ in a variety of cell systems (28). Exposure of HT29-19A monolayers to $200 \mathrm{ng} / \mathrm{ml}$ PT for $18 \mathrm{~h}$ did not influence the secretory response to $20 \mathrm{nM}$ PGE $_{2}$ (Isc $\left[\mu \mathrm{A} / \mathrm{cm}^{2}\right]$ : untreated $27.2 \pm 2.5[n=10]$; PT treated $25.1 \pm 1.6[n=7])$ or the integrity of the cell monolayer (resistance $\left[\Omega / \mathrm{cm}^{2}\right]$ : untreated $269 \pm 20.3$; PT treated $311 \pm 40.1[n$ $=14]$ ). However, PT treatment reduced by over $80 \%$ the inhibition of $\mathrm{PGE}_{2}$-stimulated secretion by SST and CLON (Fig. 1) and effectively reversed their inhibitory effects on stimulated cAMP accumulation (Fig. 3).

To confirm that PT was acting on $\mathrm{G}_{\mathrm{i}}$-like proteins in this system we examined the ability of PT to ADP-ribosylate substrates in membranes from HT29-19A cells (Fig. 4). Incubation of membranes with activated PT $(2 \mu \mathrm{g})$ in the presence of $\left[{ }^{32} \mathrm{P}\right]$ NAD selectively stimulated the labeling of a $41-\mathrm{kD}$ protein. The intensity of other labeled bands was not increased by PT. In addition, incubation of intact cells with PT at concentrations used to inhibit the antisecretory actions of SST and CLON ( $200 \mathrm{ng} / \mathrm{ml} ; 18 \mathrm{~h}$ ) markedly reduced (by $\approx 80 \%$ using densitometric analysis) the subsequent labeling of the $41-\mathrm{kD}$
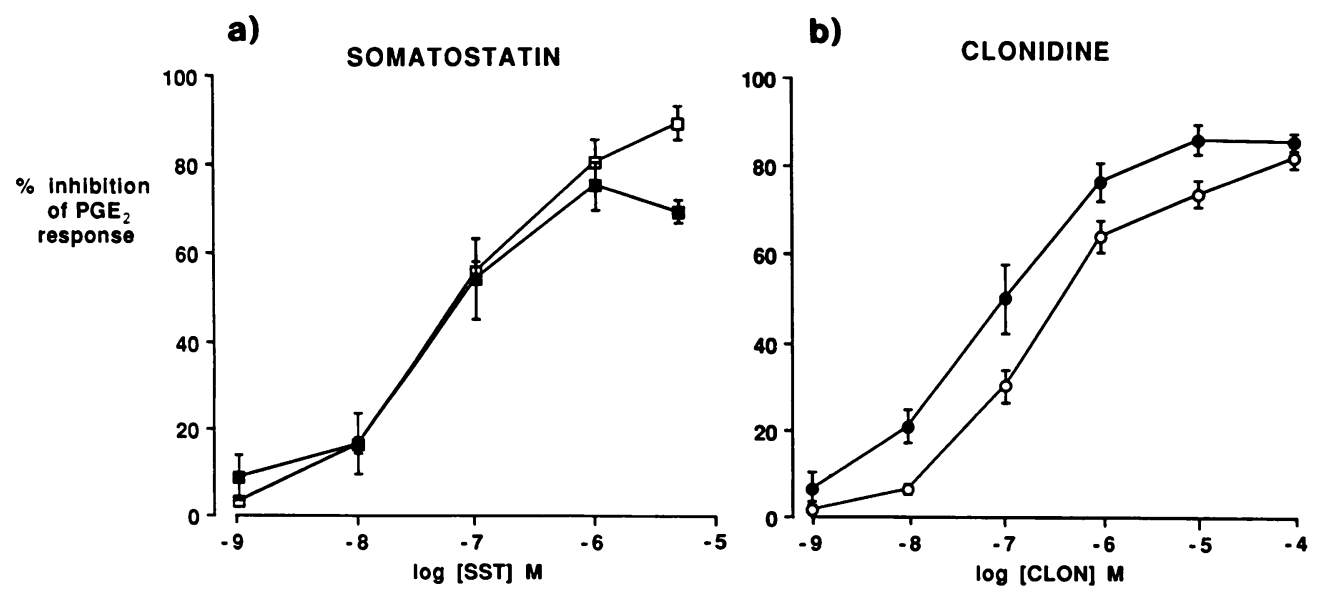

Figure 2. Dose dependence of (a) SST- and (b) CLON-induced inhibition of PGE $_{2}$-stimulated Isc $(\square, 0)$ or cAMP accumulation $(\bullet, \bullet)$ measured in HT29-19A monolayers grown on permeable supports. Results are expressed as a percentage of inhibition of the response to $20 \mathrm{nM}$ (Isc) or $100 \mathrm{nM}$ (cAMP) $\mathrm{PGE}_{2}$. These concentrations represent the approximate $\mathrm{EC}_{50}$ 's for $\mathrm{PGE}_{2}$ stimulation of the two parameters. Results for Isc show maximal inhibition of Isc measured 3 min after addition and are adjusted for the spontaneous decrease in $\mathrm{PGE}_{2}$-stimulated Isc over the same period (5.4 $\left.\pm 1.5 \%\right)$. cAMP accumulation in response to PGE $\mathrm{P}_{2}$ was measured in cells preincubated for 10 min with SST or CLON and compared to untreated cells. Data shown are mean \pm SEM for four to seven filters at each point. Basal and PGE $_{2}$-stimulated cAMP levels were $3.2 \pm 1.4(n=6)$ and $188.9 \pm 22.0(n=12) \mathrm{pmol} / \mathrm{mg}$ protein, respectively. 


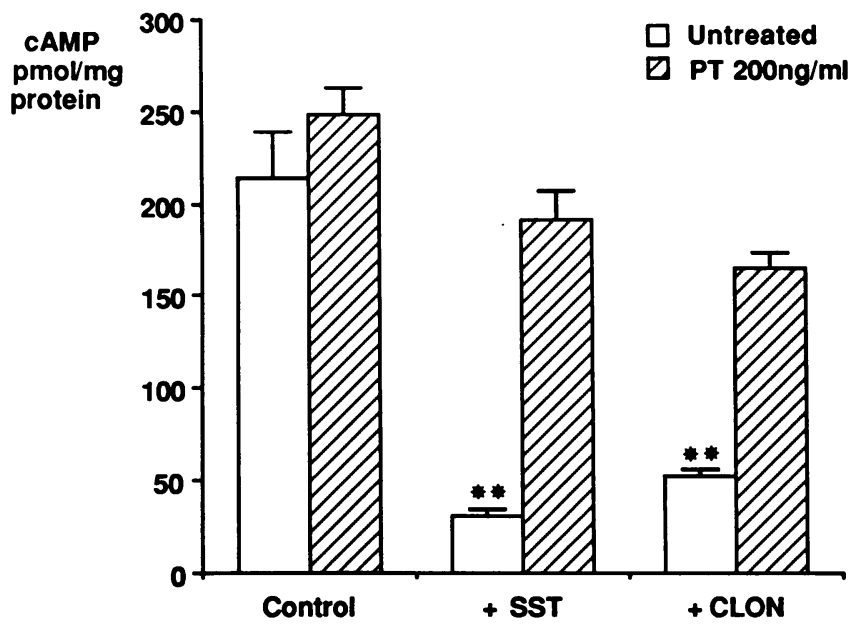

Figure 3. Reversal of SST and CLON inhibition of $\mathrm{PGE}_{2}$-stimulated cAMP accumulation by pertussis toxin. Cells were preincubated with SST $(1 \mu \mathrm{M})$, CLON $(10 \mu \mathrm{M})$, or Ringer's solution for $10 \mathrm{~min}$ before addition of $100 \mathrm{nM} \mathrm{PGE}_{2}$ in the presence of $0.2 \mathrm{mM}$ IBMX. Incubation was continued for $10 \mathrm{~min}$. Where indicated cells were pretreated for $18 \mathrm{~h}$ with $200 \mathrm{ng} / \mathrm{nl}$ PT. ${ }^{* *} P<0.01$ indicates inhibition of cAMP accumulation in response to SST or CLON compared to control. Results are mean \pm SEM from five separate monolayers in each group.

band by PT in vitro (Fig. 4), confirming that PT can modify G-proteins in intact HT29-19A cells.

The ability of SST to inhibit secretion caused by CT, which permanently activates $G_{s}$ (stimulatory guanine nucleotidebinding protein) resulting in a prolonged increase in cellular cAMP in intestinal cells, was also assessed. Table I shows that the rise in Isc stimulated by CT could be significantly inhibited by SST though inhibition was generally lower (45-50\%) than that observed for the receptor agonist $\mathrm{PGE}_{2}$. These effects were also accompanied by a reduction in the ability of CT to raise cAMP levels though, interestingly, the level of inhibition of cAMP accumulation was greater $(\approx 80 \%)$, suggesting that for CT there is a poorer correlation between Isc and cAMP than was observed for $\mathrm{PGE}_{2}$. The effects of SST appear to be largely independent of CT concentration with both supramaximal ( 2 $\mu \mathrm{g} / \mathrm{ml})$ and $\approx \mathrm{EC}_{50}(0.002 \mu \mathrm{g} / \mathrm{ml})$ doses exhibiting similar

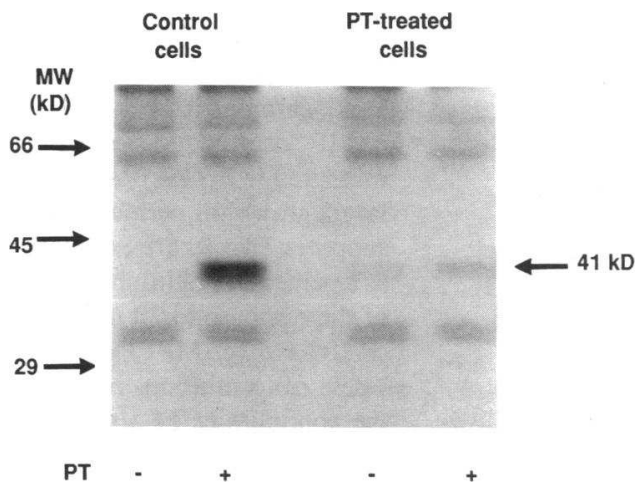

Figure 4. ADP-ribosylation of $41-\mathrm{kD}$ protein by pertussis toxin in HT29-19A membranes. Membranes prepared from control or PTtreated cells $(200 \mathrm{ng} / \mathrm{ml} ; 18 \mathrm{~h})$ were incubated with $\left[{ }^{32} \mathrm{P}\right]$ NAD for $60 \mathrm{~min}$ in the absence or presence of activated PT $(20 \mu \mathrm{g} / \mathrm{ml})$ as described in Methods. After SDS-PAGE labeled proteins were detected by autoradiography. levels of inhibition. Experiments with CT and CLON produced similar responses (results not shown).

Studies in intact intestine have shown significant reductions in basal ion transport in response to SST and CLON. In HT29-19A monolayers, however, these agonists had no effect on Isc in the unstimulated state (Isc $\left[\mu \mathrm{A} / \mathrm{cm}^{2}\right]$ : basal $3.5 \pm 0.7$; $+\mathrm{SST}(1 \mu \mathrm{M}) 3.26 \pm 1.3 ;+\mathrm{CLON}(100 \mu \mathrm{M}) 2.9 \pm 0.6[n=5])$.

Increasing evidence suggests that some of the cellular effects of agonists that activate $G_{i}$-proteins may be mediated at sites distal to second messenger production (11). We, therefore, examined the effects of SST and CLON on the secretory response to the permeant cAMP analogue, db-cAMP. db-cAMP ( 200 $\mu \mathrm{M})$ caused a sustained activation of Isc in HT29-19A cells (Fig. 5). The addition of SST $(1 \mu \mathrm{M})$ at the peak of this response elicited a significant $(P<0.005) 30-35 \%$ inhibition of Isc-an effect that did not occur in PT-treated cells. CLON ( 10 $\mu \mathrm{M})$ produced a virtually identical response $(37.3 \pm 2.8 \%$ inhibition of Isc measured $3 \mathrm{~min}$ after addition [ $n=7]$ ). Similar results were obtained using an alternative cAMP analogue, 8bromo cAMP (results not shown).

Though the kinetics of inhibition were similar to those observed with the receptor-mediated agonist, $\mathrm{PGE}_{2}$ comparison of the dose-response curves for SST inhibition of the two secretagogues (Fig. 6) showed interesting differences. First, unlike $\mathrm{PGE}_{2}$, the maximal inhibition of db-cAMP-stimulated secretion that could be achieved with SST was significantly lower ( $40 \%$ vs. $85 \%$ ), even though concentrations of $\mathrm{PGE}_{2}$ and dbcAMP were chosen to produce similar increases in Isc ( $\mathrm{PGE}_{2}$ [20 nM] 26.3 \pm 2.4 ; db-cAMP [200 $\mu \mathrm{M}$ ] 20.8 $\pm 2.1 \mu \mathrm{A} / \mathrm{cm}^{2}$ ). Secondly, the maximum inhibition of secretion stimulated by $200 \mu \mathrm{M}$ db-cAMP could be achieved at a significantly lower concentration of SST $(0.1 \mu \mathrm{M})$. Despite these differences it was notable that the calculated $\mathrm{EC}_{\mathbf{5 0}}$ 's for SST inhibition were virtually identical for each secretagogue ( $35 \mathrm{nM}\left[\mathrm{PGE}_{2}\right] ; 30$ $\mathrm{nM}$ [db-cAMP]). The effectiveness of SST as an inhibitor of db-cAMP-stimulated secretion appeared to be critically dependent on the concentration of db-cAMP used (Fig. 7). While SST was able to inhibit secretion induced by low concentrations $(100 \mu \mathrm{M})$ of db-cAMP by up to $60 \%$ at higher concentrations $(>400 \mu \mathrm{M})$ inhibition was negligible.

These data suggest that the cAMP-activated secretory pathway in HT29-19A colonocytes has $\mathrm{G}_{\mathrm{i}}$-regulated sites located both proximal and distal to cAMP production which mediate the antisecretory actions of SST and CLON. Experiments were also conducted to examine the additivity of SST and CLON effects on db-cAMP-activated cells (Fig. 8). Separate addition of either agonist caused a 30-40\% inhibition of Isc. However, when SST and CLON are added sequentially the inhibitory response to the second agonist is clearly attenuated producing a much less than additive response. Similar results were obtained when SST and CLON were added simultaneously. This may indicate that SST and $\alpha_{2}$-ADR receptors linked to the inhibition of secretion are coupled to a common pool of $\mathrm{G}_{\mathrm{i}}$-proteins.

Inhibition of secretion stimulated by $\mathrm{Ca}^{2+}$-mobilizing agonists. The $\mathrm{Ca}^{2+} / \mathrm{PKC}$ signaling system represents a second, discrete mechanism by which agonists can stimulate the $\mathrm{Cl}^{-}$secretory process in HT29-19A and other colonic cell lines (20, 29 ). We therefore investigated the ability of antisecretory agonists to modulate secretion stimulated by this route. We initially examined the effects of SST and CLON on the Isc response to the muscarinic agonist, $\mathrm{CCh}$. In this cell line $\mathrm{CCh}$ $(200 \mu \mathrm{M})$ elicited a modest increase in Isc (6-7 $\mu \mathrm{A})$ compared to that seen with cAMP agonists. (Fig. $9 A$ ). Pretreatment with 
Table I. Inhibition of CT-stimulated Isc and cAMP Accumulation by SST

\begin{tabular}{|c|c|c|c|c|c|c|}
\hline & \multicolumn{3}{|c|}{ Isc } & \multicolumn{3}{|c|}{ cAMP } \\
\hline & $\begin{array}{l}\text { Before } \\
\text { SST }\end{array}$ & $\begin{array}{l}\text { After } \\
\text { SST }\end{array}$ & $\begin{array}{l}\text { Percent inhibition } \\
\text { by SST }\end{array}$ & Without SST & With SST & $\begin{array}{l}\text { Percent inhibition } \\
\text { by SST }\end{array}$ \\
\hline & \multicolumn{2}{|c|}{$\mu \mathrm{A} / \mathrm{cm}^{2}$} & \multicolumn{4}{|c|}{ pmol/mg protein } \\
\hline CT $(2 \mu \mathrm{g} / \mathrm{ml})$ & $34.7 \pm 5.4$ & $19.1 \pm 2.7^{*}$ & 45 & $1118 \pm 87$ & $233 \pm 10^{\ddagger}$ & 79 \\
\hline CT $(0.002 \mu \mathrm{g} / \mathrm{ml})$ & $14.5 \pm 2.0$ & $7.1 \pm 1.7^{*}$ & 51 & $370 \pm 19$ & $79 \pm 12^{\ddagger}$ & 78 \\
\hline
\end{tabular}

Isc: Pre-SST values represent the peak Isc response to CT (normally 120-140 min after addition) recorded immediately before addition of $1 \mu \mathrm{M}$ SST to the basolateral bathing medium. Post-SST values are Isc recorded $3 \mathrm{~min}$ after SST addition. In all cases basal Isc has been subtracted. cAMP: CT was added to HT29-19A monolayers bathed in Ringer's solution containing $0.2 \mathrm{mM}$ IBMX; after 30 min $1 \mu \mathrm{M}$ SST was added and the incubation was continued for a further $90 \mathrm{~min}$. The filters were then washed rapidly in ice-cold Ringer's solution and cellular cAMP was extracted and assayed as described in Methods. Values are mean \pm SEM for four or five monolayers in each group.

${ }^{*} p<0.05 ; \quad{ }^{\ddagger} P<0.01$ compared to monolayers without SST.

SST $(1 \mu \mathrm{M})$ or CLON $(10 \mu \mathrm{M}) 5 \mathrm{~min}$ before CCh addition caused a $65-75 \%$ inhibition of the peak Isc response to $200 \mu \mathrm{M}$ $\mathrm{CCh}$. Inhibition could be reversed by pretreating cells with PT, suggesting that this effect is also mediated through PT-sensitive G-proteins (Fig. 9 B). Preliminary studies suggest that SST has similar effects on other receptor-mediated $\mathrm{Ca}^{2+}$ agonists including ATP and neurotensin (results not shown).

To investigate the possibility that inhibition is exerted at the level of the $\mathrm{Ca}^{2+}$ signaling pathway itself, we examined the effects of SST on $\mathrm{CCh}$-induced $\mathrm{IP}_{3}$ production and the subsequent mobilization of intracellular calcium, $[\mathrm{Ca}]_{i}$. CCh stimulated a threefold increase in cellular $\mathrm{IP}_{3}$ levels which peaked 8-10 s after agonist addition followed by a slow decline towards basal (Fig. 10). Pretreatment with $1 \mu \mathrm{M}$ SST had no significant effect on $\mathrm{CCh}$-induced $\mathrm{IP}_{3}$ production. Similar results were obtained with CLON (data not shown). The CCh-induced in-

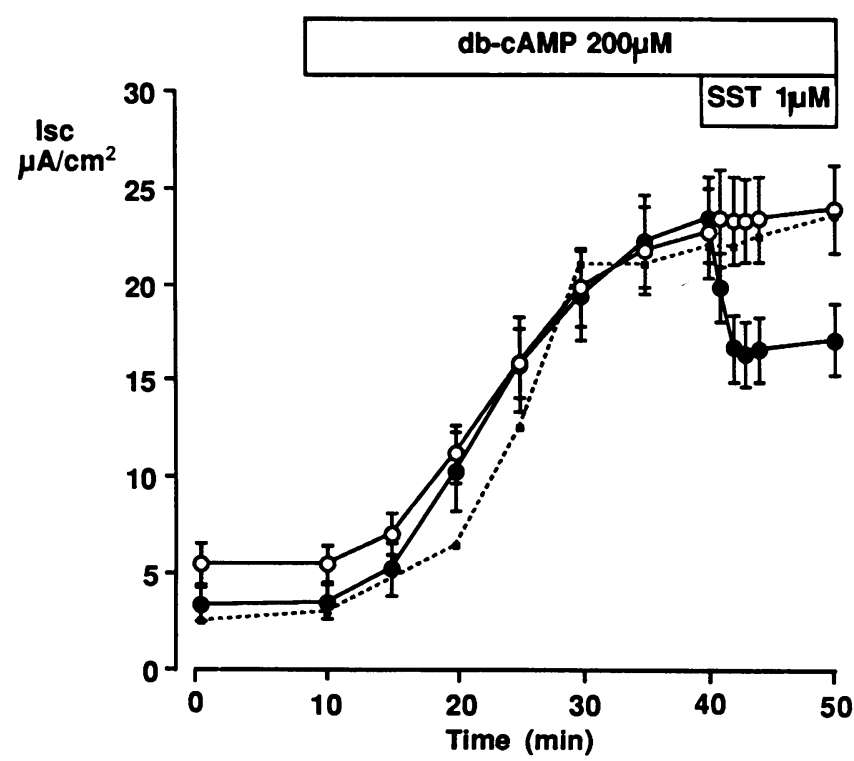

Figure 5. Inhibition of db-cAMP ( $200 \mu \mathrm{M})$-stimulated secretion by somatostatin $(1 \mu \mathrm{M})$ in $(\bullet)$ untreated and (O) PT-treated $(18 \mathrm{~h} ; 200$ $\mathrm{ng} / \mathrm{ml}$ ) monolayers. PT treatment had no significant effect on basal or db-cAMP-stimulated Isc compared to controls. Values are mean \pm SEM for six experiments. The decrease in Isc after SST addition in non-PT-treated cells was highly significant $(P<0.005$; paired $t$ test) when compared with the Isc immediately before SST addition. No significant decrease in Isc occurred after SST addition in PTtreated cells. Dotted line shows typical response to $200 \mu \mathrm{M}$ db-cAMP. creases in $\mathrm{IP}_{3}$ were associated with a rapid increase in $[\mathrm{Ca}]_{i}$ measured in cells grown on permeable supports using the calcium sensitive indicator, Fura-2 (Fig. 11). After washout of the $\mathrm{CCh}$ cells were incubated for $5 \mathrm{~min}$ with SST before being stimulated again with $\mathrm{CCh}$ (Fig. 11, upper trace). SST did not influence either the peak rise in $[\mathrm{Ca}]_{\mathrm{i}}$ after readdition of $\mathrm{CCh}$ ([Ca $]_{\mathrm{i}}$ above basal (nM): CCh 114 $12, \mathrm{CCh}+\mathrm{SST}(1 \mu \mathrm{M})$ $115 \pm 6, \mathrm{CCh}+\mathrm{CLON}(10 \mu \mathrm{M}) 128 \pm 28(n=4-7)$ or the rate at which $[\mathrm{Ca}]_{\mathrm{i}}$ declined towards basal levels. Pretreatment with CLON (Fig. 11, lower trace) similarly had no significant effect on $\mathrm{CCh}$-induced $\mathrm{Ca}^{2+}$ mobilization in these cells. Similar results were obtained using HT29-19A cells grown on collagencoated glass coverslips though under these conditions there was a significantly larger response to $\mathrm{CCh}\left([\mathrm{Ca}]_{\mathrm{i}}\right.$ above basal $\left.\mathrm{nM}\right)$ : CCh 204 $\pm 11, \mathrm{CCh}+\mathrm{SST}(1 \mu \mathrm{M}) 224 \pm 17$; CCh + CLON ( 10 $\mu \mathrm{M}) 243 \pm 15(n=4-8)$. SST and CLON had no effect on basal $[\mathrm{Ca}]_{\mathrm{i}}$ levels (results not shown). These observations suggest that SST and CLON again acting through $\mathrm{G}_{\mathrm{i}}$-coupled mecha-

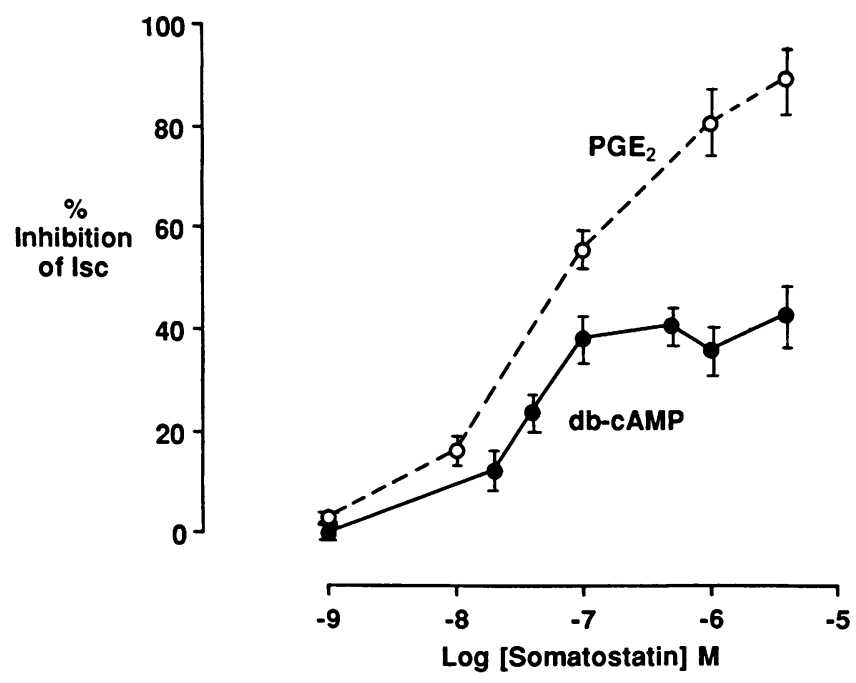

Figure 6. Dose-response relationship for SST-mediated inhibition of db-cAMP-induced increase in Isc. SST was added to monolayers 30 min after the addition of $200 \mu \mathrm{M}$ db-cAMP. Results show the percent decrease in Isc measured $3 \mathrm{~min}$ after addition of SST (solid line). Isc in db-cAMP-stimulated cells that were not exposed to SST continued to rise slowly $(0.5-1 \mu \mathrm{A})$ over this period. For comparison the doseresponse curve for inhibition of $\mathrm{PGE}_{2}$-stimulated Isc is shown (dashed line). Values are mean $\pm \mathrm{SEM}$ for four to six monolayers at each point. 


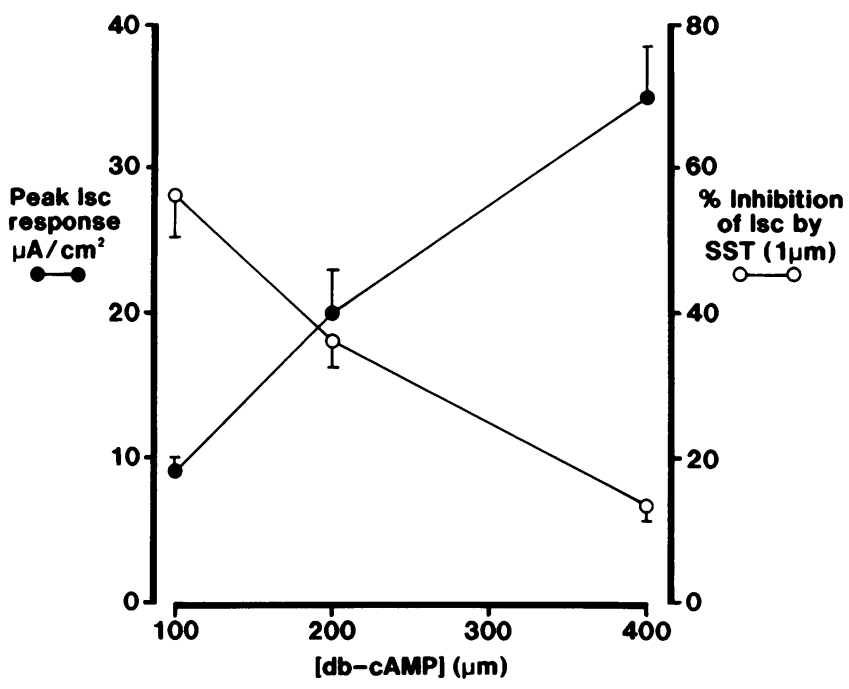

Figure 7. SST inhibition of db-cAMP-activated Isc responses in HT29-19A cells: dependence on the concentration of db-cAMP. (•) Left abscissa: peak Isc response to db-cAMP $(100-400 \mu \mathrm{M})$ in HT29-19A monolayers. (O) Right abscissa: percent inhibition by 1 $\mu$ M SST of db-cAMP ( $100-400 \mu \mathrm{M})$-stimulated Isc. Results show mean data from four to six monolayers in each group.

nisms inhibit secretion activated by $\mathrm{Ca}^{2+}$-mobilizing agonists distal to both PI turnover and $\mathrm{Ca}^{2+}$-mobilization. In an attempt to define further the site(s) of inhibition we examined (Fig. 12) the effects of SST on the rise in Isc caused by agents that either raise $[\mathrm{Ca}]_{\mathrm{i}}$ (THAP) or activate protein kinase $\mathrm{C}$ (4 $\alpha$-phorbol, 12,13-dibutyrate; PDB) without stimulating significant phosphoinositol turnover (30). THAP $(2 \mu \mathrm{M})$ caused only a minor increase in Isc $\left(1.5 \pm 0.1 \mu \mathrm{A} / \mathrm{cm}^{2}[n=9]\right)$ across HT29-19A monolayers (Fig. 12) despite the fact that its effect on $[\mathrm{Ca}]_{\mathrm{i}}$ was similar to $\mathrm{CCh}$ (data not shown). SST $(1 \mu \mathrm{M})$ added at the peak of this response caused no significant inhibi-

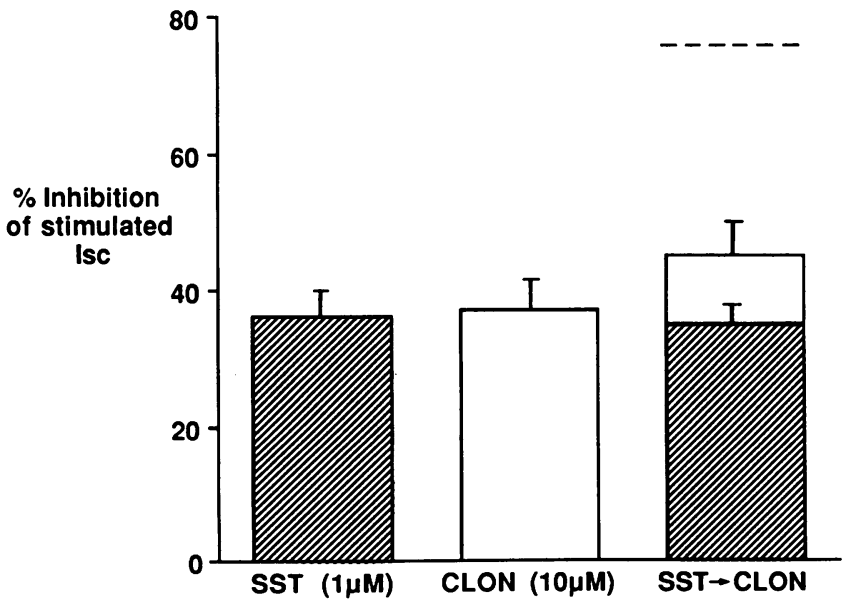

Figure 8. Nonadditivity of SST and CLON inhibition of db-cAMP-stimulated Isc in HT29-19A cells. Figure shows mean inhibition of Isc induced by SST or CLON when added separately or sequentially to HT29-19A monolayers treated with $200 \mu \mathrm{M} \mathrm{db}-$ cAMP. The inhibition in Isc was routinely recorded $4 \mathrm{~min}$ after addition. Dashed line indicates the expected inhibition if SST and CLON responses were additive. Rise in Isc above basal for db-cAMP (200 $\mu \mathrm{M}$ ) was $15.7 \pm 2.5$. Data are from five to eight monolayers in each group. tion. In contrast, low concentrations of the PKC activator, PDB ( $20 \mathrm{nM}$ ), which has been shown to activate PKC in these cells (31) stimulated a larger increase in Isc $\left(5.1 \pm 0.4 \mu \mathrm{A} / \mathrm{cm}^{2}\right.$ [ $n=7]$ ) similar to that produced by $\mathrm{CCh}$ though more prolonged (Fig. 12). In this case the addition of SST caused a rapid inhibition of Isc by $31.5 \pm 2.5 \%(n=5)$ within 2 min of addition to the basolateral surface. The simultaneous addition of THAP and PDB (Fig. 12) produced a greater than additive Isc response $\left(12.7 \pm 1.2 \mu \mathrm{A} / \mathrm{cm}^{2}[n=10]\right)$. In the presence of both agonists SST again caused an inhibition of $29.0 \pm 6 \%(n=5)$.

These data indicate that, in this cell line, activation of PKC and not increases in $[\mathrm{Ca}]_{\mathrm{i}}$ may be the primary activator of $\mathrm{Cl}^{-}$ secretion though there is clearly a synergistic interaction between these two components of the $\mathrm{Ca}^{2+}$ pathway similar to that observed in the T84 cell line. The differential effect of SST would suggest that its ability to inhibit secretion induced by receptor-mediated $\mathrm{Ca}^{2+}$ agonists such as $\mathrm{CCh}$ may be due, at least in part, to the inhibition of a PKC-activated component of the $\mathrm{Cl}^{-}$secretory process in HT29-19A cells.

\section{Discussion}

The present studies show that the peptide, SST and the $\alpha_{2}$ ADR agonist, CLON can act directly on the HT29-19A colonic cell line to inhibit the Isc, presumably due to $\mathrm{Cl}^{-}$secretion, induced by both cAMP- and $\mathrm{Ca}^{2+}$-dependent agonists. This effect mimics their antisecretory effects in the whole intestine. These actions appear to be mediated at multiple sites along the secretory pathway involving inhibition of cAMP generation but also at sites activated by CAMP and PKC activators which lie distal to second messenger production. Inhibition of Isc stimulated by all types of secretagogue could be effectively reversed by pretreating cells with PT at concentrations which cause the ADP-ribosylation of a 41-kD G $\mathrm{i}_{\mathrm{i}}$-like protein in HT29-19A membranes.

Our studies suggest that the inhibition of CAMP generation is an important mechanism by which SST and CLON attenuate $\mathrm{Cl}^{-}$secretion in these cells. $\mathrm{G}_{\mathrm{i}}$ activation is commonly associated with an inhibition of adenylate cyclase and the PT-sensitive attenuation of CAMP accumulation by SST and CLON in HT29-19A cells is similar to that observed in other cell types. Other antisecretory agonists have been shown to limit cAMP production in intestinal cells including neuropeptide Y (32) and adenosine agonists acting through $A_{1}$ receptors (33). While the involvement of $G_{i}$ was not tested in these studies it seems likely that the ability to lower intestinal cAMP levels through a $\mathrm{G}_{\mathrm{i}}$-linked mechanism may be a common feature of many agonists that act to limit secretion. In these studies there was a close relationship between the ability of SST to inhibit cAMP production and to reverse the $\mathrm{Cl}^{-}$secretion induced by agonists which raise cellular CAMP, suggesting that this may be a primary site of action for this agent. In the case of CLON, however, there appeared to be some dissociation between inhibition of the two parameters. Several recent observations in other cells also suggest that the relationship between $G_{i}$-linked effects and the inhibition of CAMP may not be so clear-cut. In the shark rectal gland, adenosine agonists were able to inhibit completely forskolin-stimulated $\mathrm{Cl}^{-}$secretion despite significantly elevated cAMP levels (33). Similarly, in the T84 cell line, secretion induced by high concentrations of $\mathrm{PGE}_{2}$ could be maintained despite a marked inhibition of CAMP production (34). SST and $\alpha_{2}$-ADR also inhibited cAMP-mediated fluid secretion in intact mucosal preparations without signifi- 

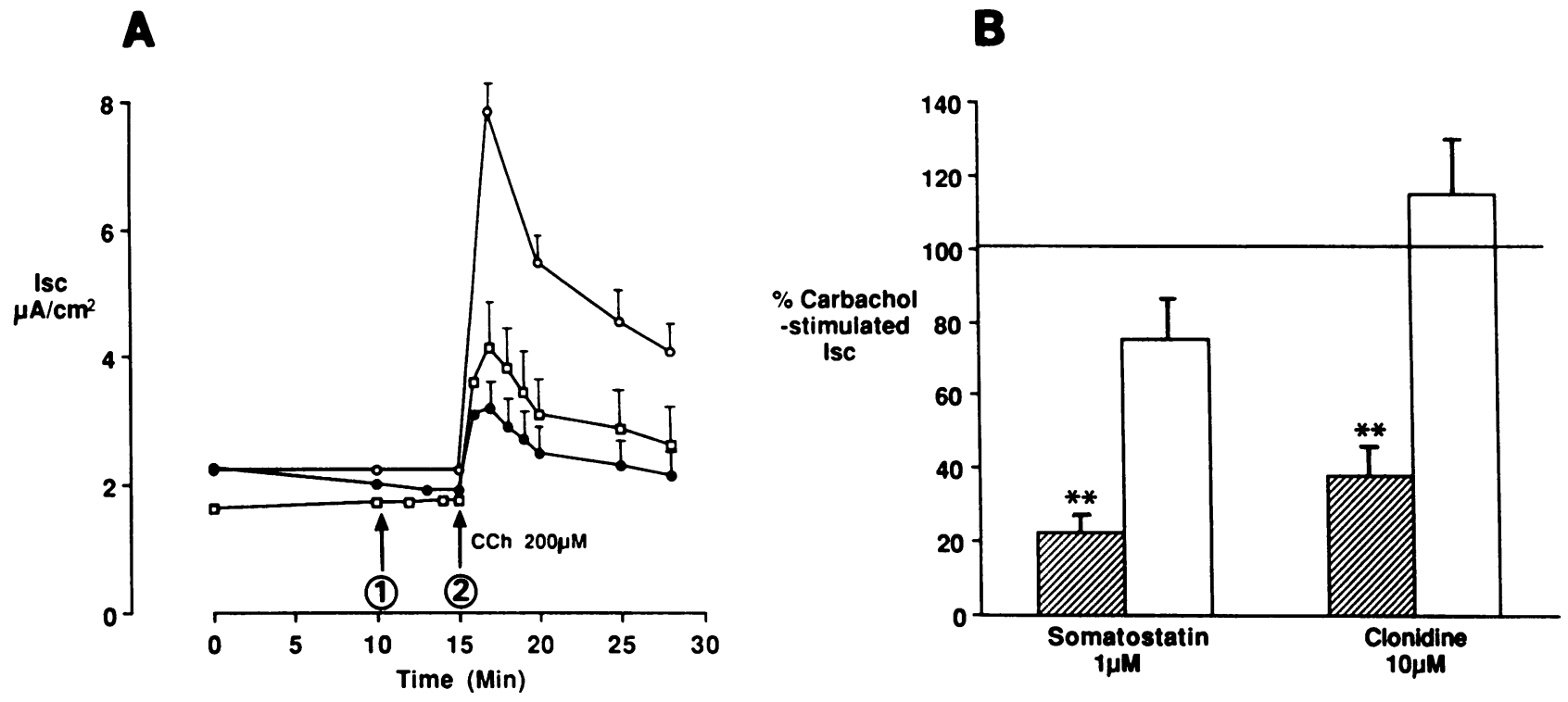

Figure 9. Effects of SST and CLON on CCh-stimulated Isc responses in HT29-19A cells. $(A)$ Cells were pretreated for 5 min with $(\bullet) 1 \mu$ M SST, () $10 \mu \mathrm{M}$ CLON, or ( $($ ) Ringer's solution (Arrow 1) before addition of $200 \mu \mathrm{M}$ CCh (Arrow 2). SST and CLON elicited a significant inhibition $(P<0.01)$ of the CCh-induced Isc increase. Results are mean of six experiments in each group $(B)$ Reversal of SST- and CLON-induced inhibition of CCh by PT. Results show effect of SST and CLON on CCh-induced Isc rise in cell monolayers pretreated with $200 \mathrm{ng} / \mathrm{ml}$ pertussis toxin for $18 \mathrm{~h}$ (open bars) or in untreated monolayers (hatched bars). Cells were exposed to SST or CLON 5 min before CCh and data are expressed as a percentage of the normal response to $\mathrm{CCh}$. Results are mean $\pm \mathrm{SEM}$ from five monolayers in each group. ${ }^{* *} P<0.005$.

cant changes in tissue cAMP levels $(27,35,36)$ though in this case the possibility remains that measurements of whole mucosal cAMP may mask changes in specific epithelial "pools" of cAMP.

There is considerable evidence from the present study, however, that while the ability to lower epithelial cAMP levels is a characteristic property of antisecretory agents, they also interact with the secretory pathway at additional G-protein-linked sites which bypass the adenylate cyclase system.

First, SST and CLON were able to partially inhibit secretion induced by the permeant cAMP analogues, db-cAMP and 8-bromo cAMP - an effect that was also blocked by PT.

Secondly, both agonists were also effective inhibitors of secretion induced by the receptor-mediated $\mathrm{Ca}^{2+}$-mobilizing ago-

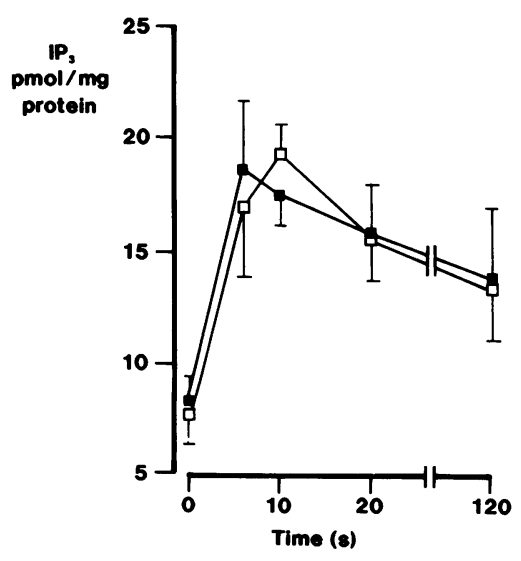

Figure 10. Effect of SST $(1 \mu \mathrm{M})$ on CCh-induced increase in $\mathrm{IP}_{3}$ levels in HT29-19A cells. Cells grown to confluency in 22-mm plastic dishes were washed free of medium and suspended in Hepes-Ringer's solution before addition of $(\square)$ $1 \mu \mathrm{M}$ SST or ( $\square$ ) solvent. After 5 min medium was aspirated and replaced by fresh Ringer's solution con-

taining either (ם) $100 \mu \mathrm{M}$ CCh or ( ()$\left.^{\prime}\right) 100 \mu \mathrm{M}$ CCh $+1 \mu \mathrm{M}$ SST. After incubation for $0-120 \mathrm{~s}$ reactions were stopped by rapid aspiration and addition of ice-cold perchloric acid. Cellular $\mathrm{IP}_{3}$ was extracted and assayed as described in Methods. Results are mean \pm SEM from five determinations.

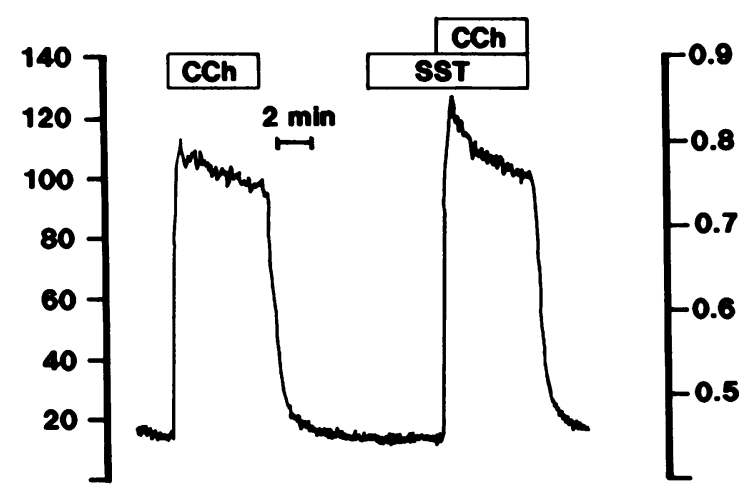

$\left[\mathrm{Ca}^{27}\right]$
(nW)
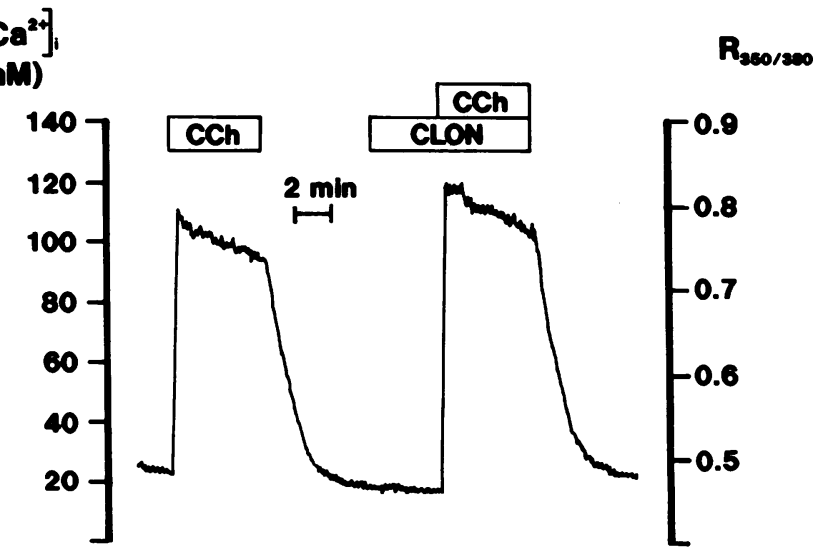

Figure 11. Effects of SST (upper trace) and CLON (lower trace) on CCh-induced increases in [Ca $]_{i}$ in HT29-19A cells. [Ca $]_{i}$ was measured in Fura-2-loaded cells grown on permeable supports as described in Methods. Results show representative tracings from four experiments in each group. The axis on the right shows the 350/380$\mathrm{nm}$ ratio which was used to calculate the $[\mathrm{Ca}]_{\mathrm{i}}$ values (in $\mathrm{nM}$ ) shown on the left axis. Mean data for the peak rise in $[\mathrm{Ca}]_{i}$ induced by $\mathrm{CCh}$ in the presence and absence of SST/CLON are given in the text. 


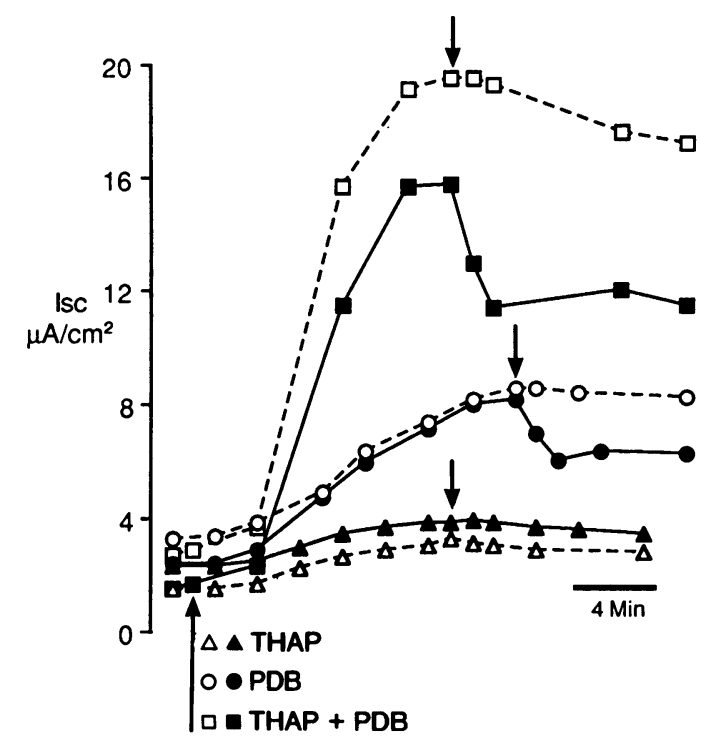

Figure 12. SST inhibition of Isc activated by THAP and PDB in HT29-19A monolayers. $2 \mu \mathrm{M}$ THAP $(\Delta, \Delta), 20 \mathrm{nM}$ PDB $(\circ, \bullet)$, or a combination of both $(\square, \square)$ was added to cell monolayers as indicated. At the peak of the Isc response either $1 \mu \mathrm{M}$ SST $(\Delta, \bullet, \bullet)$ or solvent control $(\Delta, O, \square)$ were added indicated by the arrow. Results are representative data from one of at least four similar experiments for each condition.

nist, $\mathrm{CCh}$ reducing its effects by $60-70 \%$. This action, again reversed by PT, occurred without any apparent inhibition of either $\mathrm{IP}_{3}$ production or increases in cytosolic free calcium, $[\mathrm{Ca}]_{i}$. Other studies with somatostatin in intestinal cells have also implied a site of action distal to the rise in $[\mathrm{Ca}]_{\mathrm{i}}$ though in neither case was the involvement of G-proteins investigated. A preliminary study in chicken enterocytes showed that epinephrine had no effect on agonist-stimulated increases in $[\mathrm{Ca}]_{\mathrm{i}}$ despite being a potent inhibitor of $\mathrm{Ca}^{2+}$ dependent secretion in the intact mucosa (37) while in T84 cells high concentrations of SST $(10 \mu \mathrm{M})$ were shown to inhibit $\mathrm{Cl}$ secretion induced by a calcium ionophore (17). In some tissues there is evidence that SST acting through $G_{i}$ can modulate some aspects of the $\mathrm{Ca}^{2+}$ signaling pathway including inhibition of $\mathrm{Ca}^{2+}$ channel opening (38) but we could find no evidence for this occurring in HT29-19A cells. The results of experiments using selective activators of the $\mathrm{Ca}^{2+}$ and $\mathrm{PKC}$ arms of the signaling pathway provide some indication that SST may act distally to inhibit a PKC-activated component of $\mathrm{Cl}^{-}$secretion. Increasing [Ca $]_{i}$ alone with THAP appears to be a poor activator of $\mathrm{Cl}^{-}$secretion generating minor increases in Isc in these cells. However, $\mathrm{PDB}$, an activator of $\mathrm{PKC}$ produced significant increases in Isc particularly when added simultaneously with THAP. Similar effects of PKC-activators have been reported in a recent study of HT29-19A cells by Bajnath et al. $(31,39)$, suggesting that PKC-dependent processes play a significant role in activating the $\mathrm{Cl}^{-}$secretory process in these cells. The ability of SST to induce a rapid, although partial, inhibition ${ }^{-}$of PDB-induced secretion while having no significant effect on that induced by THAP alone suggests that SST acts to inhibit $\mathrm{Ca}^{2+} / \mathrm{PKC}-\mathrm{de}-$ pendent secretion at a PKC-activated site in these cells. The ability of SST to inhibit the actions of PDB coupled with its lack of effect on $\mathrm{IP}_{3}$ (and therefore by inference associated diacylglycerol production) suggests a site of action distal to the activation of PKC itself. The possibility that SST may influ- ence diacylglycerol production generated from other sources such as the breakdown of phosphatidylcholine must also be considered (40).

The characteristics of inhibition observed using nonreceptor agonists to stimulate secretion were somewhat different from those seen with receptor mediated agonists. The secretion induced by nonreceptor agonists generally appeared to be more difficult to inhibit with both db-cAMP and PDB (25-50\%) showing a lesser degree of inhibition than either $\mathrm{PGE}_{2}$ or $\mathrm{CCh}$ $(60-80 \%)$. In addition, with db-cAMP, the maximum level of inhibition appeared to be critically dependent on the extent to which the $\mathrm{Cl}^{-}$secretory process had been stimulated. Thus, at concentrations of db-cAMP $>400 \mu \mathrm{M}$ (Isc rise $40 \mu \mathrm{A}$ ) inhibition was negligible while the same concentration of SST caused a $50 \%$ reduction in secretion induced by $100 \mu \mathrm{M} \mathrm{db}$-cAMP (Isc rise $10 \mu \mathrm{A}$ ). One explanation for this may be that $G_{i}$-like proteins regulate a distal site or sites which become increasingly rate limiting at suboptimal stimulation of the secretory pathway. Similarly, agonists that bypass the normal second messenger synthesis/degradation processes may be inherently more difficult to inhibit. The relative sensitivity of receptor-mediated agonists to SST and CLON would presumably result from inhibition being mediated at both proximal and distal sites.

The nature of the distal inhibitory site in HT29-19A cells remains uncertain. Both cAMP agonists and PKC activators have been shown to stimulate apical $\mathrm{Cl}^{-}$secretion in these cells but cause relatively small increases in basolateral $\mathrm{K}^{+}$movement $(20,39)$. Raising $[\mathrm{Ca}]_{\mathrm{i}}$ alone appears to have the opposite effect-stimulating large increases in basolateral $\mathrm{K}^{+}$efflux with much smaller effects on apical $\mathrm{Cl}^{-}$secretion (20; and manuscript in preparation). Similar observations have been made in the T84 cell line where increases in $[\mathrm{Ca}]_{\mathrm{i}}$ were also shown to have a greater effect on basolateral $\mathrm{K}^{+}$permeability than on apical $\mathrm{Cl}^{-}$channels (41). In preliminary studies we have found that SST has no influence on CCh-stimulated ${ }^{86} \mathrm{Rb}$ efflux in HT29-19A despite significantly inhibiting the CCh-induced rise in Isc (G. Warhurst, unpublished observations). It is interesting to speculate from the differential effect of SST on these components that at least one site lies in close proximity to the apical $\mathrm{Cl}^{-}$channel. Receptors linked through $\mathrm{G}_{\mathrm{i}}$ have been shown to couple to ion conductances in a variety of cell types $(11,38)$ and there is growing evidence that G-proteins play a role in regulating ion channels in intestinal epithelial cells. Recent studies have identified a G-protein activated $\mathrm{Cl}^{-}$channel in the HT29-19A cell line (42) while G-proteins have also been implicated in the negative modulation of $\mathrm{K}^{+}$conductances in guinea pig enterocytes (43) an action that could also result in the attenuation of transepithelial ion secretion.

Several G-proteins acting as substrates for PT have been identified including at least three subtypes of $G_{i}$ and it has been suggested that these may couple to specific receptors or that different subtypes may allow the same receptor to link to different effector systems (44). A recent study has shown that enterocyte membranes express the PT-sensitive G-protein subtypes, $\alpha_{\mathrm{i}-2}$ and $\alpha_{\mathrm{i}-3}(23)$ though their involvement in regulating specific epithelial functions remains to be determined. Identification of the specific G-protein subtypes involved in coupling SST and CLON receptors to proximal and distal inhibitory sites in the secretory process and their location in apical or basolateral membrane domains will, clearly, be an important progression of the observations made in the present study.

In the whole intestine there are likely to be multiple cellular sites at which antisecretory agonists may act including neuro- 
nal elements, endocrine cells, immune cells, and the epithelium itself. Action at all these sites may contribute, directly or indirectly, to the overall inhibition of secretion. However, the observations in this study that SST and CLON, acting through PT-sensitive G-proteins, can inhibit a broad range of secretagogues in a functional epithelial model system suggests that the epithelium is likely to be an important site of action for antisecretory agonists.

\section{Acknowledgments}

The authors thank Dr C. L. Laboisse, INSERM, Paris, for providing the HT29-19A clonal cell line.

This work was supported by Sir Jules Thorne Charitable Trust and the Wellcome Trust, UK.

\section{References}

1. Dharmsathaphorn, K., R. S. Sherwin, and J. W. Dobbins. 1980. Somatostatin inhibits fluid secretion in the rat jejunum. Gastroenterology. 78:813-820.

2. Keast, J. R., J. B. Furness, and M. Costa. 1986. Effects of noradrenaline and somatostatin on basal and stimulated mucosal ion transport in the guinea pig small intestine. Naunyn-Schmeideberg's Arch. Pharmacol. 333:393-399.

3. Knobloch, S. F., M. Diener, and W. Rummel. 1989. Antisecretory effects of somatostatin and vasopressin in the rat colon descendens in vitro. Regul. Pept. 25:75-85.

4. Pamukcu, R., and E. B. Chang. 1990. Alpha-2-adrenergic agonists as antidiarrheal agents: a review of physiological and cellular mechanisms. In Textbook of Secretory Diarrhea. E. Lebenthal and M. Duffey, editors. Raven Press, New York. 383-408.

5. Donowitz, M., S. Levine, and A. Watson. 1990. New drug treatments for diarrhoea. J. Intern. Med. 228:155-163.

6. Brown, D. R., M. F. Overend, and B. G. Treder. 1990. Neurohormonal regulation of ion transport in the porcine distal jejunum: actions of somatostatin14 and its natural and synthetic homologs. J. Pharmacol. Exp. Ther. 252:126134.

7. Weber, M., T. Cole, and J. M. Conlon. 1985. Specific binding and degradation of somatostatin by membrane vesicles from pig gut. Am. J. Physiol. 250:G679-685.

8. Chang, E. B., M. Field, and R. J. Miller. 1983. Enterocyte alpha-2-adrenergic receptors: yohimbine and $p$-aminoclonidine binding relative to ion transport. Am. J. Physiol. 244:G76-82.

9. Limbird, L. E., and J. D. Sweatt. 1985. Alpha-2-adrenergic receptors: apparent interaction with multiple effector systems. In The Receptors. Volume 2. P. M. Conn, editor. Academic Press, Inc., New York. 281-307.

10. Toro, M. J., L. Birnbaumer, M. C. Redon, and E. Montoya. 1988. Mechanism of action of somatostatin. Horm. Res. 29:59-64.

11. Limbird, L. E. 1988. Receptors linked to inhibition of adenylate cyclase: additional signalling mechanisms. FASEB J. 2:2686-2695.

12. Inoue, L., and M. Yoshi. 1992. Modulation of ion channels by somatostatin and acetylcholine. Prog. Neurobiol. 38:203-230.

13. van den Berghe, N., N. J. Nieuwkoop, A. B. Vaandrager, and H. R. de Jonge. 1991. Asymmetrical distribution of G-proteins among the apical and basolateral membranes of rat enterocytes. Biochem. J. 278:565-571.

14. Turner, J. T., C. Ray-Prenger, and D. B. Bylund. 1985. Alpha-2-adrenergic receptors in the human cell line, HT29: characterization with full agonist radioligand $\left[{ }^{3} \mathrm{H}\right]$ UK-14, 304 and inhibition of adenylate cyclase. Mol. Pharmacol. 28:422-430.

15. Bouscarel, B., C. Cortinovis, C. Carpene, J. C. Murat, and H. Paris. 1985. Alpha-2-adrenoreceptors in the HT29 human colon adenocarcinoma cell line: characterisation with $\left[{ }^{3} \mathrm{H}\right]$ clonidine: effects on cyclic AMP accumulation. Eur. J. Pharmacol. 107:223-231.

16. Jones, S. B., and D. B. Bylund. 1988. Characterisation and possible mechanisms of alpha-2-adrenergic receptor-mediated sensitisation of forskolin-stimulated cyclic AMP production in HT29 cells. J. Biol. Chem. 263:14236-14244.

17. Dharmsathaphorn, K., K. G. Mandel, J. A. McRoberts, L. D. Tisdale, and H. Masui. 1984. A human colonic tumor cell line that maintains vectorial electrolyte transport. Am. J. Physiol. 246:G204-208.

18. Augeron C., J. J. Maoret, C. L. Laboisse, and E. Grasset. 1986. Permanently differentiated cell clones isolated from the human colonic adenocarcinoma cell line HT29: possible models for the study of ion transport and mucus production. In Ion Gradient Coupled Transport. INSERM Symp. 26:363-366.

19. Warhurst, G., N. B. Higgs, M. Lees, A. Tonge, and L. A. Turnberg. 1988. C-kinase modulation of cAMP production and electrical responses to prostaglandin $E_{2}$ in a colonic epithelial cell line. Am. J. Physiol. 255:G27-32.
20. Vaandrager, A. B., Bajnath, R., Groot, J. A., Bot, A. G. M. and H. R. de Jonge. 1991. $\mathrm{Ca}^{2+}$ and cAMP activate different chloride efflux pathways in HT29.cll9A colonic epithelial cell line. Am. J. Physiol. 261:G958-G965.

21. Palmer, S., K. T. Hughes, D. Y. Lee, and M. J. O. Wakelam. 1989. Development of a novel, $\operatorname{Ins}(1,4,5) \mathrm{P}_{3}$-specific binding assay. Its use to determine the intracellular concentration of $\operatorname{Ins}(1,4,5) \mathrm{P}_{3}$ in unstimulated and vasopressinstimulated rat hepatocytes. Cell. Signalling. 1:147-156.

22. Grynkiewicz, G., M. Poenie, and R. Y. Tsien. 1985. A new generation of $\mathrm{Ca}^{2+}$ indicators with greatly improved fluorescence properties. J. Biol. Chem. 280:3440-3450.

23. van den Berghe, N., Nieukoop, N. J., Vaandrager, A. B., and H. R. de Jonge. 1991. Asymmetrical distribution of G-proteins among the apical and basolateral membranes of rat enterocytes. Biochem. J. 278:565-571.

24. Balda, M. S., Gonzalez-Mariscal, L., Contreras, R. G., Macias-Silva, M. Torres-Marquez, M. E., Garcia-Sainz and M. Cereijido. 1991. Assembly and sealing of tight junctions: possible participation of G-proteins, phospholipase C, protein kinase C and calmodulin. J. Membr. Biol. 122:193-202.

25. Laemmli, U. K. 1970. Cleavage of structural proteins during assembly of the head of bacteriophage T4. Nature (Lond.). 227:680-685.

26. Chang, E. B., M. Field, and R. J. Miller. 1982. Alpha-2-adrenergic receptor regulation of ion transport in rabbit ileum. Am. J. Physiol. 242:G237-G242.

27. Guandalini, S., J. F. Kachur, P. L. Smith, R. J. Miller and M. Field. 1980. In vitro effects of somatostatin on ion transport in rabbit intestine. Am. J. Physiol. 238:G67-74.

28. Katada, T., and M. Ui. 1982. Direct modification of the membrane adenylate cyclase system by islet-activating protein due to ADP-ribosylation of a membrane protein. Proc. Natl. Acad. Sci. USA. 79:3129-3133.

29. Dharmsathaphorn, K., J. Cohn, and G. Beuerlein. 1989. Multiple calcium-mediated effector mechanisms regulate chloride secretory responses in T84 cells. Am. J. Physiol. 256:C1224-1230.

30. Thastrup, O. 1990. Role of $\mathrm{Ca}^{2+}$-ATPase in regulation of cellular $\mathrm{Ca}^{2+}$ signalling as studied with the selective microsomal $\mathrm{Ca}^{2+}$-ATPase inhibitor, thapsigargin. Agents Actions. 29:8-15.

31. van den Berghe, N., A. B. Vaandrager, A. G. M. Bot, P. J. Parker, and H. R. de Jonge. 1992. Dual role for protein kinase $C \alpha$ as a regulator of ion secretion in the HT29cl. 19A human colonic cell line. Biochem. J. 285:673-679.

32. Voisin, T., C. Rouyer-Fessard, and M. Laburthe. 1990. Distribution of common peptide $\mathrm{YY}$-neuropeptide $\mathrm{Y}$ receptor along rat intestinal villus-crypt axis. Am. J. Physiol. 258:G753-759.

33. Kelley, G. G., E. M. Poeschla, H. Barron, and J. N. Forrest, Jr. 1990. A adenosine receptors inhibit chloride transport in the shark rectal gland: dissociation of inhibition and cyclic AMP. J. Clin. Invest. 85:1629-1636.

34. Warhurst, G., N. B. Higgs, A. Tonge, and L. A. Turnberg. 1991. Stimulatory and inhibitory actions of carbachol on chloride secretory responses in human colonic cell line, T84. Am. J. Physiol. 261:G220-G228.

35. Donowitz, M., S. Cusolito, L. Battisti, R. Fogel, and G. W. G. Sharp. 1982. Dopamine stimulation of active $\mathrm{Na}$ and $\mathrm{Cl}$ absorption in rabbit ileum: interaction with alpha-2-adrenergic and specific dopamine receptors. J. Clin. Invest. 69:1008-1016.

36. Nakai, T., T. Nakadate, S. Yamanoto, and R. Kato. 1982. Alpha-2-adrenergic inhibition of intestinal secretion induced by prostaglandin $E_{1}$, vasoactive intestinal peptide and dibutyryl-cAMP in rat jejunum. J. Pharmacol. Exp. Ther. 220:637-641.

37. Chang, E. B., A. J. Gill, N. S. Wang, and M. Field. 1984. Alpha-2-adrenergic inhibition of Ca-dependent intestinal secretion. Gastroenterology. 85:1044. (Abstr.)

38. Rosenthal, W., J. Hescheler, R. Eckert, S. Offermanns, A. Schmidt, K. D. Hinsch, K. Spicher, W. Trautwein, and G. Scultz. 1990. Pertussis toxin-sensitive G-proteins: participation in the modulation of voltage-dependent $\mathrm{Ca}^{2+}$ channels by hormones and neurotransmitters. Adv. Second Messenger Phosphoprotein Res. 24:89-95.

39. Bajnath, R. B., M. H. van Hoeve, H. R. de Jonge, and J. A. Groot. 1992. Regulation of apical $\mathrm{Cl}^{-}$conductance and basolateral $\mathrm{K}^{+}$conductances by phorbol esters in HT29cl-19A cells. Am. J. Physiol. 263:C759-C766.

40. Exton, J. H. 1990. Signalling through phosphatidylcholine breakdown. $J$. Biol. Chem. 265:1-4.

41. Cartwright, C. A., J. A. McRoberts, K. G. Mandel, and K. Dharmsathaphorn. 1985. Synergistic action of cyclic adenosine monophosphate- and calcium-mediated chloride secretion in a colonic epithelial cell line. J. Clin. Invest. 76:1837-1842.

42. Tilly, B. C., M. Kansen, P. J. M. van Gageldonk, N. van den Berghe, H. Galjaard, J. Bijman, and H. R. de Jonge. 1991. G-proteins mediate intestinal chloride channel activation. J. Biol. Chem. 266:2036-2040.

43. Fargon, F., P. A. McNaughton, and F. V. Sepulveda. 1990. Possible involvement of GTP-binding proteins in the deactivation of an inwardly rectifying $\mathrm{K}^{+}$current in enterocytes isolated from guinea-pig intestine. Pflügers Arch. Eur. J. Physiol. 417:240-242.

44. Milligan, G., I. Mullaney, and F. R. McKenzie. 1990. Specificity of interactions of receptors and effectors with GTP-binding proteins in native membranes. In G-proteins and Signal Transduction. Biochem. Soc. Symp. 56:21-35. 